\title{
Distribution and Potential Limiting Factors of the European Pond Turtle (Emys orbicularis) in Eastern Europe
}

\author{
Oksana Nekrasova ${ }^{1,2, * \mathbb{D}}$, Oleksii Marushchak ${ }^{1}$, Mihails Pupins ${ }^{2}$, Arturs Skute ${ }^{2}$, Volodymyr Tytar ${ }^{1}$ and \\ Andris Čeirāns ${ }^{2}$ \\ 1 I. I. Schmalhausen Institute of Zoology, National Academy of Sciences of Ukraine, 01030 Kyiv, Ukraine; \\ ecopelobates@gmail.com (O.M.); vtytar@gmail.com (V.T.) \\ 2 Department of Ecology, Institute of Life Sciences and Technologies, Daugavpils University, \\ LV5400 Daugavpils, Latvia; mihails.pupins@gmail.com (M.P.); arturs.skute@du.lv (A.S.); \\ andris.ceirans@lu.lv (A.Č.) \\ * Correspondence: oneks22@gmail.com; Tel.: +38-067-217-1970
}

Citation: Nekrasova, O.; Marushchak, O.; Pupins, M.; Skute, A.; Tytar, V.;

Čeirāns, A. Distribution and Potential Limiting Factors of the European Pond Turtle (Emys orbicularis) in Eastern Europe. Diversity 2021, 13, 280. https://doi.org/10.3390/ d13070280

Academic Editor: Luc Legal

Received: 27 April 2021

Accepted: 15 June 2021

Published: 22 June 2021

Publisher's Note: MDPI stays neutral with regard to jurisdictional claims in published maps and institutional affiliations.

Copyright: (c) 2021 by the authors. Licensee MDPI, Basel, Switzerland. This article is an open access article distributed under the terms and conditions of the Creative Commons Attribution (CC BY) license (https:/ / creativecommons.org/licenses/by/ $4.0 /)$.

\begin{abstract}
In order to use an integrated approach for studying the influence of risk factors on the distribution of the native turtle species E. orbicularis and accompanying invasive species (T. scripta and N. procyonoides) in the northeast of their range, we used GIS modelling and a database (GAEZ, human footprint, CliMond) of 55 preselected variables, which represent a system of bioclimatic and anthropogenic factors. The main variables that influenced the results were factors related to temperature. There was a high correlation $(r=0.6)$ between the species distribution model's habitat suitability for E. orbicularis and the corresponding "human footprint" values within the European part of the species' natural range. Its unpretentiousness towards anthropogenic factors would likely help the further expansion of its range in eastern Europe, because the areas with the highest habitat suitability $(r>0.7)$ were projected to increase 3.3-fold. When comparing the E. orbicularis model to those obtained for $N$. procyonoides and T. scripta, we concluded that $N$. procyonoides could be dangerous because it occupies similar habitats (the degree of correlation is reasonably high in the north of their range $(r=0.5)$ in Latvia). An expansion of the range of Trachemys scripta is also possible in the future within the northern territories. Therefore, when developing the turtles' protection algorithms, it is also necessary to take into account the influence of invasive species.
\end{abstract}

Keywords: Emys orbicularis; distribution; invasive species; GIS modelling; changing of the climate

\section{Introduction}

Currently, it is evident that the environment is changing under the influence of anthropogenic pressure and climatic changes, including the habitats of autochthonous species of animals. For most thermophilic animals, their natural range spans from tens to hundreds of kilometers to the north, especially in eastern Europe [1-3]. However, the emergence of new invasive species can often affect the distribution of autochthonous species, not only by competing for available resources, but also by directly feeding on them $[4,5]$. The complex influences of anthropogenic factors, climatic changes, and invasive species on the distribution of the European pond turtle, Emys orbicularis (Linnaeus, 1758), has been studied and reported in several publications [6-8]. Moreover, the pond turtle has often been used as a model organism for studying events in the Holocene in northern and central Europe [9-13]. Currently, this species is vulnerable, especially at the borders of its range, since, in addition to changing climatic conditions [14-16], marginal populations of turtles appear to be under the influence of invasive species such as the red-eared slider, Trachemys scripta (Thunberg in Schoepff, 1792), and the raccoon dog, Nyctereutes procyonoides (Gray 1834), which especially affects their clutches and juvenile turtles $[4,17]$. European pond turtles occupy freshwater areas (ponds, lakes, slow-moving rivers, channels, etc.), selecting terrestrial locations with open sandy soil habitats suitable for making clutches $[18,19]$. In Ukraine 
they are found mainly in large bodies of water with fresh water, a slow current, lush vegetation and a depth of more than $60 \mathrm{~cm}$ in order to survive winter hibernation [20,21]. However, they have also been registered in cattle trenches, the brackish waters of estuaries and coastal wetlands $[17,20]$. E. orbicularis is a rare and protected herpetofauna species in Ukraine, Latvia and their neighboring countries $[15,17,21]$; nonetheless, in Ukraine, according to our own observations, this species is more abundant than in neighboring countries. E. orbicularis is listed in Resolution No 6 of the Bern Convention (1979) Emys orbicularis (1220), which means that this species requires the development of Emerald Network sites in the territories it inhabits for its protection [21]. Additionally, the species is listed in the Annexes II and IV of Council Directive 92/43/EEC, in Appendix II of the Bern Convention (1979), and in the IUCN Red List of Threatened Species, assessed as a lower risk/near threatened (LR/NT) species [21]. Due to its biotope generalism and its associated tendency to be synanthropic and colonize a wide range of water habitats, its ability to cover distances of several kilometers and its omnivorous diet, T. scripta is an indirect threat to the native E. orbicularis [22], acting as its competitor for food resources [23,24] and an agent for the transmission of non-native pathogens [25]. It appeared in Ukrainian freshwater bodies as a result of the illegal pet trade and subsequent releases, both intentional and unintentional [26]. With a currently expanding distribution area to the north as a result of global climate change, as well as it being released by local people, T. scripta is already confirmed to be producing viable clutches in some European countries, e.g., Croatia [27], indicating a potential serious negative impact on local biota. Nyctereutes procyonoides occupies a wide range of territories in Polissia (forested biogeographical region which starts from the farthest edge of central Europe and encompasses eastern Europe, including eastern Poland, the Belarus-Ukraine border and western Russia) and the forest-steppe zone, preferring wet meadows with swampy lowlands, overgrown river floodplains and riverine forests with dense undergrowth; moreover, Nyctereutes procyonoides is unpretentious when choosing places to inhabit. It is quite often spotted in territories with light soils, and sometimes near arid areas along small waterbodies, which is where the turtles breed [28]. This omnivorous species, whose diet consists of various food items (fruits, insects and small vertebrates (including pond turtles)), was widely introduced in the former Soviet Union as a fur animal in the 1950s, and it has now also become a widely distributed invasive species in the European Union [28]. Its number in Ukraine has increased significantly in recent decades while, in Latvia, it has been observed since 1943 and 15000 individuals were registered in 2006 [28]. Regarding this, we hypothesized that, despite climate change and the possibility of the turtle's (E. orbicularis) "shift" to the north, anthropogenic influences and newly emerging biotic components of ecosystems (invasive species (predators and competitors)) may be important risk factors to consider.

Therefore, the purpose of our work was not only to study the distribution of the European pond turtle in the northern part of its range in eastern Europe, in the context of climatic and anthropogenic changes, but also to investigate the limiting factors that could affect this process.

\section{Materials and Methods}

\subsection{Occurrence Data Collection}

Occurrence data was made up of original information of the species' registrations from field investigations (actual observations of living animals or findings of their remnants) in Latvia (1985-2021, Pupins M., Pupina A.) and Ukraine (1996-2021, Nekrasova O.), preserved collection material (I. I. Shmalhausen Institute of Zoology NAS Ukraine, Kyiv), literature [20,24,28-32] and GBIF databases (E. orbicularis [33], N. procyonoides [34], T. scripta [35], http:/ / www.gbif.org/ (accessed on 3 April 2021). Data from the different sources were filtered to remove duplicate records. To account for sampling bias, we used the nearest neighbor distance ('ntbox' package in $\mathrm{R},[36]$ ) method to thin the data, where occurrence points that were $\leq 0.1$ units (decimal degrees) away from each other were removed to avoid errors due to spatial autocorrelation. As a result, the number of points was signif- 
icantly reduced to 2278 points (georeferenced records) for E. orbicularis, 1525 points for N. procyonoides and 1410 points for T. scripta.

\subsection{Environmental Data}

We used 35 bioclimatic predictor data sourced from the CliMond dataset ([37]; https:/ / www.climond.org/ (accessed on 5 March 2021), A1B emission scenario, GCM: MIROC $\mathrm{H}$ ). The CliMond variables represent annual trends (e.g., mean annual temperature, annual precipitation) and extreme limiting environmental factors (e.g., temperature of the coldest and warmest months, precipitation in the wettest or driest quarter), and are known to influence species distributions [38]. Of 35 bioclimatic variables, highly correlated $(r>0.7)$ predictors were removed using the "virtualspecies" package in R [39], resulting in a selection of 18 variables for 1975 (1961-1990) and 2090 (2081-2100).

As proxies for human disturbance of natural systems we used human footprint (HF variables) maps compiled from remotely sensed and bottom-up survey information on eight variables, measuring the direct and indirect human pressures on the environment globally [22,40-42]. Data on human pressures were acquired or developed by Venter et al. (2016): hfoot, population density, electric infrastructure (night light), crop lands, pasture lands, built environments, railways. Pressures were then overlaid to create the standardized HF maps.

We also used a system of bioclimatic and anthropogenic factors (IIASA/FAO, 2012) and Global Agro-ecological Zones which were (GAEZ v3.0, http:/ / www.fao.org/ (accessed on 5 March 2021): median altitude, annual temperature range, temperature growing period, reference evapotranspiration, terrain slope index, temperature sum during temperature growing period, temperature sum during frost-free period, dominant land cover pattern, frost-free period, thermal climates, reference length of growing period zones and thermal zones-for bioclimatic modelling.

All rasters (CliMond, GAEZ, HF) were resampled in SAGA GIS (System for Automated Geoscientific Analyses, v. 7.6.0) to the same extension and resolution of 5 arcminutes.

\subsection{Model Building}

Maxent software (v.3.3.3k, [43]) was utilized for modeling, using the default settings. Maxent, unlike other distributional modeling techniques, uses only presence and background data instead of presence and absence data. We separately fitted Maxent models and ran Bioclim analyses for each target species and each dataset of predictors (CliMond, GAEZ, HF). Logistic output format was used to describe the relative probability of presence, which was a continuous habitat suitability (HS) range between 0 (unsuitable) and 1 (the most suitable). The area under the receiver operating characteristic (ROC) curve (AUC) was used for assessing the discriminatory capacity of the models: in all obtained models, the AUC value was $>0.85$, which is considered good [44]. Here, we employed maximum entropy (MaxEnt) niche modelling (jackknife testing of variable importance, 25 replicates, random test percentage 25, replicate runs type bootstrap) as a tool to assess potential HS for target species in Europe, putting special emphasis on anthropogenic impact. After this step, the obtained models were compared using DivaGis и SAGA multiple regression analysis modules. We used DivaGis modelling to run Bioclim and looked for the limiting factors of each target species, computing their percent influence, optimal range of values and relative confidence intervals. Using the Spearman's rank correlation, we assessed statistically significant positive correlations $(p<0.05)$ between the predicted HS map obtained through Maxent for every single target species and the human footprint (HF) map across the study area. We carried out separate modelling for each set of factors and for each species, as well as separately calculated the correlation coefficient for each country and territory. GIS modelling was accomplished using SagaGis, DivaGis and QGis software [45]. Statistical processing of the obtained data was carried out using Statistica for Windows v.10. 


\section{Results}

As a result of our field studies, it was found that the number of pond turtles in the Ukrainian population had increased in the last decade. This trend was found even in the populations the northeast of Ukraine where, until the end of the 20th century, this species had not been registered [29]. At the moment, the number of turtles in the woodlands of Ukraine is approximately six individuals per $1 \mathrm{~km}$ of a roadside ditch (2013, Polissia Nature Reserve); on the southern border of the Polissia biogeographical zone in the large metropolis of Kyiv, up to 25 E. orbicularis and 5 T. scripta were found in one lake (2020, the area of the reservoir is $12.3 \mathrm{ha}$ ) [21,29], despite the fact that, 10 years earlier, only single finds had been recorded in Polissia and in the forest-steppe biogeographical region of Ukraine [46]. The average number (density) of the pond turtle population in Belarusian Polissia is currently about $3-5$ individuals per $1 \mathrm{~km}$ of riverbed [17]. However, there is an assumption that the northern boundary of the pond turtles' distribution has fluctuated considerably over the last half century; for example, in the region of Belarus [47]. The unique findings from breeding E. orbicularis in the very north of the range in Latvia (four confirmed cases of successful breeding) [30] only confirm a positive effect of climate change, which contributes to the expansion of E. orbicularis range to the northeast.

As a result of GIS modelling, and by comparing predictions of the Maxent SDM fitted on the CliMond (18 CliMond dataset variables) (1975) dataset, which were projected across Europe under "current" and future (2090) climatic conditions, it was found that the pond turtle's habitat could expand 3.3-fold (highest habitat suitability $>0.7$ ) in the future in eastern Europe. According to GIS modelling data (Maxent, variables for 1975), bioclimatic factors associated with the temperature regime and radiation have had a great influence on the spread of E. orbicularis throughout Europe: bio20 (annual mean radiation; $\mathrm{W} \mathrm{m}^{-2}$ ) was $21.4 \%$, bio1 (annual mean temperature; ${ }^{\circ} \mathrm{C}$ ) was $15.4 \%$, bio10 (mean temperature of the warmest quarter; ${ }^{\circ} \mathrm{C}$ ) was $13 \%$. Bio20 denoted the variable that would contribute the most in jackknife testing of the variables' contribution in Maxent. The environmental variable that decreased the gain the most when it was omitted was bio24, which was the radiation of the wettest quarter, which therefore appeared to have the most information that was not present with the other variables. Bioclim (DivaGis) analysis revealed that the turtle was especially vulnerable in the north of the range and was limited by temperature factors (70\% of species occurrences fell within the interval indicated for the considered variable): bio1 $+6-+17^{\circ} \mathrm{C}\left(90 \%\right.$ : $\left.+2-+20^{\circ} \mathrm{C}\right)$, bio12 (annual precipitation in $\mathrm{mm}$ ) was 300-1200 $\mathrm{mm}$ (90\%: 153-2231 mm). Maxent analysis revealed approximately the same results for two other target species (Figure 1B,C). Moreover, optimal conditions (the greatest growth of the curve on the graph) were seen after $+4{ }^{\circ} \mathrm{C}$ (the water temperature at which pond turtles usually hibernate) (Figure 1A).

The invasive exotic red-eared slider (T. scripta), which has recently appeared in eastern Europe because it is very often released into reservoirs by hobbyists, is a more thermophilic and synanthropic species. We have registered the species in all major cities of all regions of Ukraine. Trachemys scripta hibernates successfully in the southern part of Ukraine (it has been observed over the past 10 years in the Odessa region). In some bodies of water in Odessa, its number exceeds the native E. orbicularis many times over [45]. Of the 80 turtles found in the Athletic Park (Odesa), 94\% appeared to be T. scripta (8 May 2020, personal observation of O. Nekrasova). Although there have been no registered and confirmed cases of T. scripta breeding in the wild in Ukraine yet, there have been cases of oviposition in Mariupol (Donetsk Region, O. Lazarenko, personal report) and in Latvia, Daugavpils, in the outer basin.

Using Maxent, it was revealed that the most important climatic factors shaping the distribution of T. scripta were bio17 (precipitation during the driest quarter; $\mathrm{mm}$ ) contributing $27.4 \%$ to the model, bio6 ( $\min$ temperature during the coldest week; ${ }^{\circ} \mathrm{C}$ ) with a contribution of $16.6 \%$ and bio22 (lowest weekly radiation; $\mathrm{W} \mathrm{m}^{-2}$ ) contributing $16 \%$. Through jackknife testing, bio11 (mean temperature during the coldest quarter; ${ }^{\circ} \mathrm{C}$ ) appeared to have the most useful information by itself. The environmental variable that decreased the gain the most 
when it was omitted was bio3 (isothermality (bio2 $\div$ bio7)), which therefore appeared to have the most information that was not present in the other variables. Bioclim (DivaGis) analysis revealed that $T$. scripta was more vulnerable, especially in the north of the range, and was limited by temperature factors $(70 \%)$ : bio1 was $+8-+22{ }^{\circ} \mathrm{C}\left(90 \%:+3-+25^{\circ} \mathrm{C}\right)$, bio12 was $400-1500 \mathrm{~mm}$ (90\%: 200-1800 mm), for which the decrease in their values resulted in a decreasing possibility of this species surviving in the north.

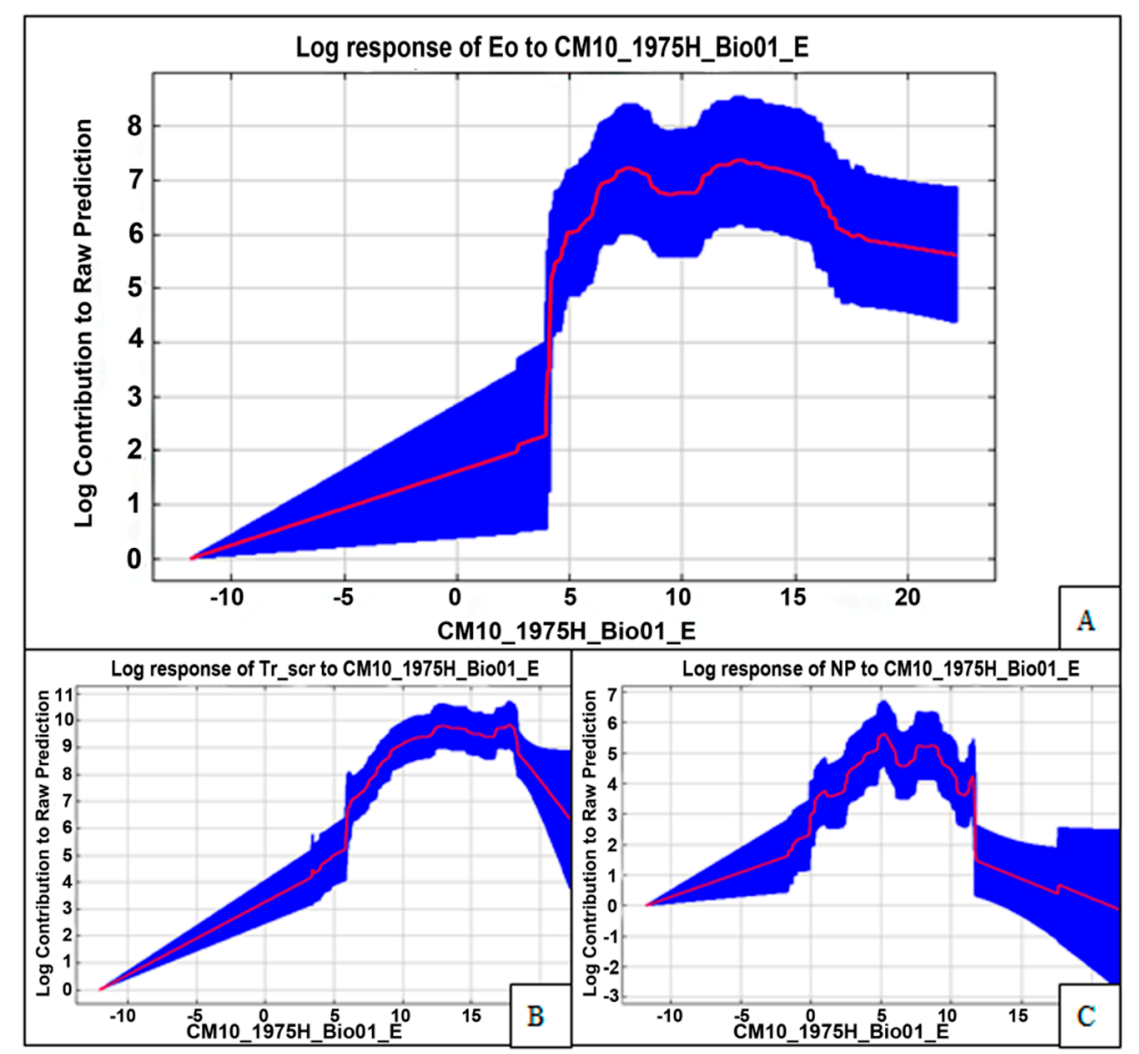

Figure 1. Maxent model created using only the variable bio1 (annual mean temperature $\left({ }^{\circ}\right.$ C, CliMond)) from: (A) E. orbicularis; (B) T. scripta; (C) N. procyonoides.

Of all three target species, the raccoon dog appeared to be the most resistant to cold. However, it often lives in biotopes near rivers and water bodies, digging holes in light soil where turtles breed. As a result of GIS modelling using Maxent, it was revealed that the important factors that affect $N$. procyonoides distribution are: bio2 (mean diurnal temperature range; ${ }^{\circ} \mathrm{C}$ ) was $14.7 \%$, bio9 (mean temperature of driest quarter; ${ }^{\circ} \mathrm{C}$ ) was $10.8 \%$ and bio22 (lowest weekly radiation; $\mathrm{W} \mathrm{m}^{-2}$ ) was $10.8 \%$. The results of the jackknife test, which was to identify variable importance, showed that bio27 (radiation of coldest quarter; $\mathrm{W} \mathrm{m}^{-2}$ ) was the most important factor for the species, having the most useful information by itself when assessed on its own; when the model was fitted with all the considered variables, bio27 did not emerge among the other, more contributing, factors. The environmental variable that decreased the gain the most when it was omitted was bio25 (radiation of driest quarter; $\mathrm{W} \mathrm{m}^{-2}$ ), which therefore appeared to have the most information that was not present in the other variables. Using DivaGis, we found that bioclimatic factors characterizing the occurrence sites of $N$. procyonoides $(70 \%)$ had a considerably wider range compared to E. orbicularis and T. scripta towards the lower end of temperature range: bio1 was $+1-+14{ }^{\circ} \mathrm{C}\left(90 \%\right.$ : $\left.+3-+18^{\circ} \mathrm{C}\right)$ and bio12 was $400-1600 \mathrm{~mm}(90 \%$ : $173-2783 \mathrm{~mm})$.

By using bioclimatic and anthropogenic predictors (GAEZ dataset, Table 1, Figures $2 \mathrm{~A}$ and 3$)$, we came to the conclusion that the greatest contributions to (>10\%) and influences on all three target species were given by the factors associated with the temperature regime, namely temperature growing period, annual temperature range and 
temperature sum during the frost-free period; however, for N. procyonoides, landscape features (median altitude (GAEZ)) were also of great importance (Table 1). Factors such as evapotranspiration seemed to be important for the distribution of both species of turtles; however, its contribution to SDM for T. scripta was considerably bigger, as this species is closely bound to aquatic biotopes (17.3\% compared with $5.6 \%$ for E. orbicularis (Table 1$)$ ).

Among the anthropogenic factors, the "human footprint" affected the distribution of all three target species; the greatest contribution were the general demographic factors, "hfoot" and human "population" density (Table 1). Additionally, the distribution of T. scripta appeared to be affected by night-time lights, possibly associated with the illumination of "warm" urban water bodies, and one of the N. procyonoides was affected by the presence of pasture land (Table 1).

According to the simulation results, it was revealed that areas that had the highest habitat suitability $(>0.7)$ almost coincide with the northern boundaries (red line in Figure 2A), drawn according to Fritz and Laufer (2007) [11,32], but we also observed a small displacement by the borders in both northern and eastern Europe. According to model projection, by 2090, E. orbicularis could shift northwards and experience an increase in suitable areas of 3.3-fold compared to the predictions under the current climate (Figure 2B).

Table 1. Bioclimatic and anthropogenic factors (human footprint, GAEZ), affecting the distribution of three model species (using Maxent). Cases where contribution and permutation were $>10 \%$ are marked with "*". "Contr." and "Permut." are abbreviated forms of the words "Contribution" and "Permutation", respectively.

\begin{tabular}{|c|c|c|c|c|c|c|}
\hline \multirow{2}{*}{ Variable } & \multicolumn{2}{|c|}{ E. orbicularis } & \multicolumn{2}{|c|}{ T. scripta } & \multicolumn{2}{|c|}{ N. procyonoides } \\
\hline & Contr. & Permut. & Contr. & Permut. & Contr. & Permut. \\
\hline \multicolumn{7}{|c|}{ GAEZ } \\
\hline Temperature growing period & $25.2 *$ & 3.3 & $16^{*}$ & 2.3 & $10.8^{*}$ & 8.1 \\
\hline Annual temperature range & 4.6 & $13.0 *$ & $15.7 *$ & $27.2 *$ & $28.6^{*}$ & $38.9 *$ \\
\hline Temperature sum during frost-free period & $11.8^{*}$ & $15.8 *$ & 0.8 & 2.1 & 2.4 & 2.8 \\
\hline Reference evapotranspiration & 5.6 & $11.3 *$ & $17.3 *$ & 38.4 * & 4.4 & 3.2 \\
\hline Median altitude & 4.1 & 4.7 & 0.6 & 2.2 & $37.1 *$ & $18.4^{*}$ \\
\hline \multicolumn{7}{|c|}{ Human footprint } \\
\hline hfoot & $56.9 *$ & $39.7 *$ & 4.8 & 3.7 & $13.6^{*}$ & 18.7 * \\
\hline population & $29.9 *$ & 29.1 * & $28.6^{*}$ & 55.0 * & 31.0 * & $19.1 *$ \\
\hline pasture & 4.8 & $10.8 *$ & 1.3 & 6.0 & 25.8 * & $26.0 *$ \\
\hline lights & 1.9 & 4.0 & $39.2 *$ & 17.5 * & 9.1 & 12.5 \\
\hline built09 & 1.7 & 4.5 & 24.6 * & 15.9 * & 12.5 * & 9.3 * \\
\hline
\end{tabular}

The invasive target species, in relation to E. orbicularis (Figures 2 and 3), occupy slightly different niches. As shown in the SDMs, T. scripta was predicted to be actively promoted in western Europe, where it would reproduce successfully and, by 2090, would become naturalized in western and southern Ukraine (Figure 4A). When analyzing suitable habitats, it was revealed that the suitable areas modelled for N. procyonoides partially overlapped with those of E. orbicularis, but to a lesser extent than when compared with T. scripta; indeed, the raccoon dog partially shares habitat requirements with E. orbicularis and T. scripta, which allows this mammal to feed on individuals and on clutches of the pond turtles. Nonetheless, the most potentially suitable habitats for this mammal are in the north of Europe, where E. orbicularis is most vulnerable (Figure 4B). 


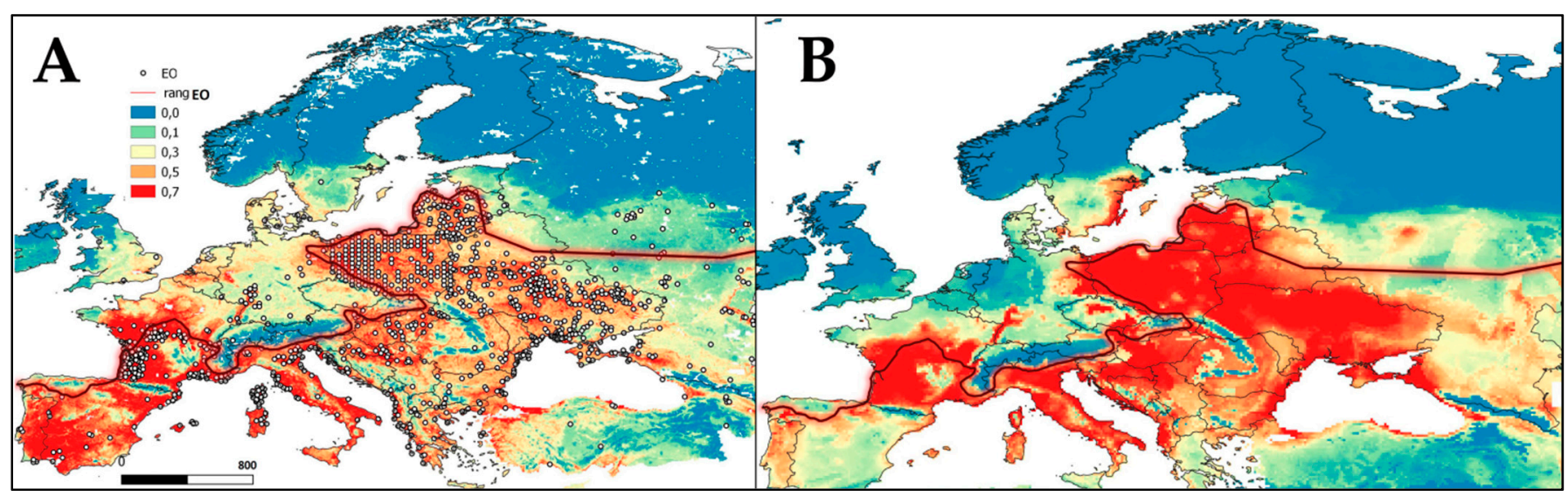

Figure 2. Potential (probabilistic) model of E. orbicularis expansion built in the Maxent program based on dataset: (A) GAEZ, current; (B) CliMond, 2090 dataset), GBIF data (2021). Areas with the highest habitat suitability (>0.5) are colored in red, and areas with the lowest $(<0.1)$ in blue. The red line displays the current northern distribution border of native populations according to Fritz and Laufer (2007) [11,32].

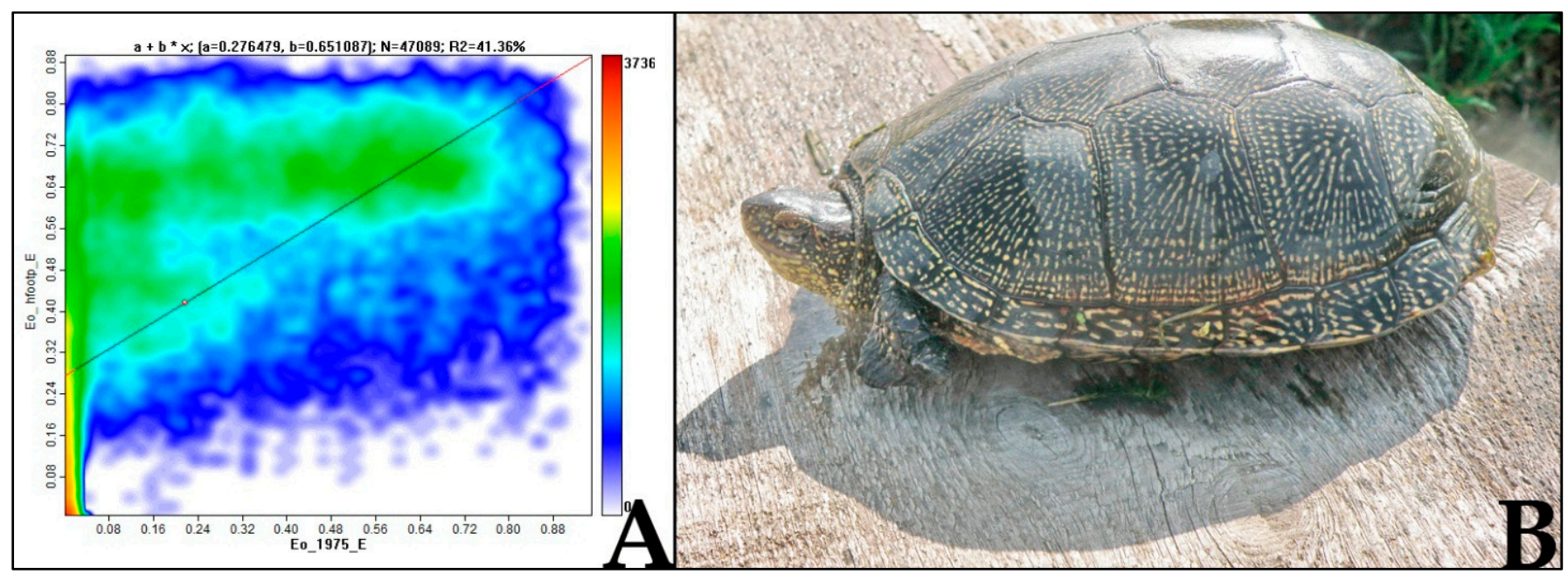

Figure 3. Results of turtles' living in anthropogenically impacted (artificial including) water bodies: (A) dependence graphs of HS from HF (grid SDM, correlation $r=0.6$, Saga); (B) anomalies of forelimbs of turtles from an artificial pond, Kinburn spit (Ukraine, 2015).

When comparing SDMs (Maxent, HS, GAEZ dataset) between N. procyonoides and E. orbicularis, and when constructing a regression model (HS modelled for E. orbicularis as a response variable and HS modelled for $N$. procyonoides as the covariate), the correlation coefficient appeared to be $r=0.6$ across Europe, as well as for Ukraine while, for Latvia (on the northern border of the species natural range), this figure was $r=0.5$.

T. scripta is a more thermophilic species that actively displaces E. orbicularis from the "warm" countries of Eastern Europe. In this case the correlation coefficient was also considerably high $(r=0.7)$. In eastern Europe, $T$. scripta could pose a threat to the native species in the southern regions (Figure 4). Therefore, when comparing SDMs of potential habitat suitability (HS, CliMond, 1975 dataset), it was revealed that, by 2090 in Ukraine, there will be suitable habitat conditions for T. scripta, and the correlation coefficient between SDMs of the two species of turtles is $r=0.2$. 


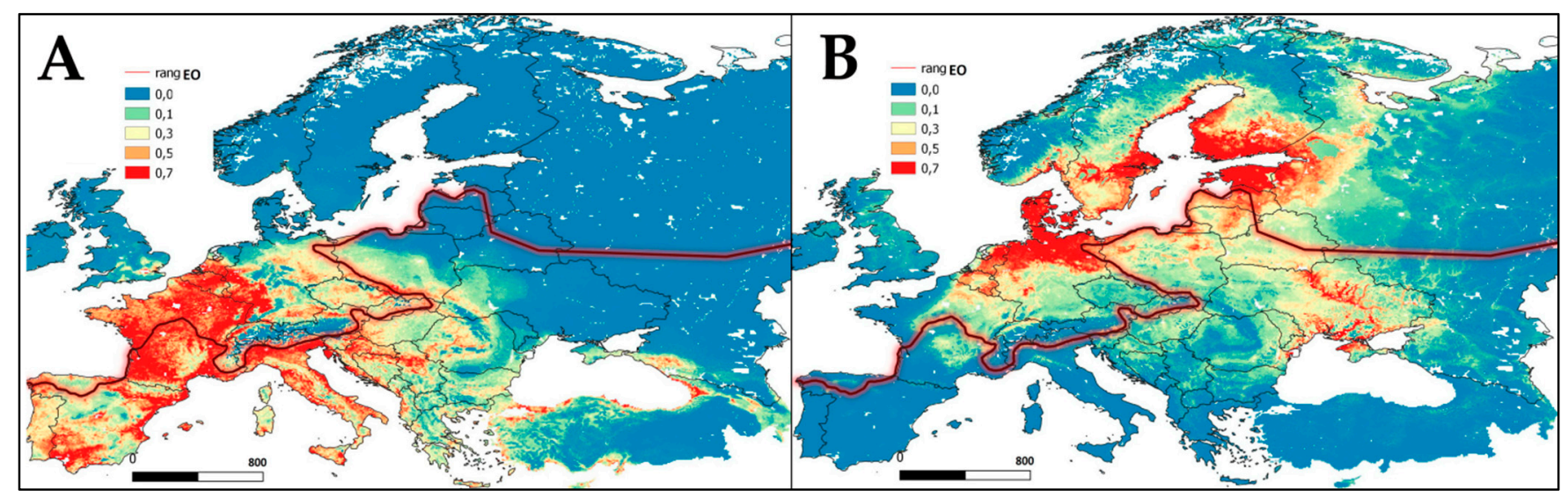

Figure 4. Potential (probabilistic) model for species expansion built in the Maxent program based on CliMond, 2090 dataset and GBIF data: (A) T. scripta; (B) N. procyonoides. Areas with the highest habitat suitability $(>0.5)$ are colored in red and areas with the lowest $(<0.1)$ in blue.

\section{Discussion}

According to the latest observations, E. orbicularis is expanding its range to the north of eastern Europe, therefore forming marginal populations. By expanding into new areas, pond turtles are subjected to new and changing climatic factors to which they may turn out to be vulnerable, for example a reduction of breeding success (only four registered breeding cases in Latvia in the wild [30]). Also predation (from N. procyonoides) or competition for a resource (involving T. scripta), can reduce the adaptive potential of species that occupies new territories (especially marginal populations). The main research result is the following: the possibility of the influence of complex anthropogenic and climatic factors (GAEZ dataset, Table 1) on the distribution of E. orbicularis was confirmed. Among the factors studied, the main factors that influenced the results were those associated with temperature. The optimal range of bio1 (annual mean temperature) (for $70 \%$ ) was found to be $+6-+17^{\circ} \mathrm{C}$. Interestingly, the high correlation $(r=0.6)$ between HS predicted by the SDM was obtained for E. orbicularis using the GAEZ dataset and HF. This confirms the fact that, due to the shortage of fresh water and the drying up of natural reservoirs, turtles often migrate into anthropogenic (artificial) equivalents, using them as refugiums (Figure 3A). This is confirmed by the large contribution of the "hfoot" variable of $56.9 \%$ in the creation of the HF SDM. Such unpretentiousness of E. orbicularis to anthropogenic factors (if there is no direct impact) is likely to help further in expanding its natural range in eastern Europe, even if occasionally such habitat choice might lead to the occurrence of morphological anomalies (Figure 3B). The areas with the highest habitat suitability $(>0.7)$ for the European pond turtle are projected to increase 3.3-fold, particularly to the north and the east. At the same time, in these possible newly colonized regions, E. orbicularis would be exposed to higher predatory pressure by N. procyonoides. Indeed, the correlation between their SDMs was 0.6 for Ukraine, as well as for Europe in general and in the north of the area (Latvia) 0.5. The expansion of T. scripta is possible from the southwest, and the correlation coefficient for its models with E. orbicularis (HS, CliMond, 1975 dataset) for Ukraine is 0.2. Therefore, when developing turtle protection systems, it is necessary to take into account the influence of a set of factors, including the rapid expansion of invasive species.

It should be stated that, although the AUC value (the method for assessing the discriminatory capacity of the models) was $>0.85$ and the areas with the highest habitat suitability had values of $>0.5$, taking into account the degree of extrapolation made by Maxent, more reliable interpreting of the obtained SDMs could be best performed using ground verification in the field. 
Author Contributions: Conceptualization, O.N., M.P. and V.T.; Data curation, O.N., M.P., A.S. and A.Č.; Formal analysis, O.N. V.T., O.M.; Funding acquisition, M.P., A.S., A.Č.; Investigation, O.N., M.P., O.M. and A.Č.; Methodology, O.N. and V.T.; Project administration, A.S., O.N., A.Č. and M.P.; Resources, O.N., M.P. and A.Č.; Software, O.N. and V.T.; Supervision, O.N., V.T. and M.P.; Validation, O.N., V.T., A.Č. and M.P.; Visualization, O.N., V.T. and M.P.; Writing-original draft and Writing-review \& editing, author: O.N., V.T., M.P., A.Č., O.M. and A.S. All authors have read and agreed to the published version of the manuscript.

Funding: This research was funded by Fundamental and Applied Research Projects (FLPP), grant number lzp-2020/2-0070.

Institutional Review Board Statement: Not applicable.

Informed Consent Statement: Not applicable.

Data Availability Statement: The data presented in this study are available on request from the corresponding author. The data are not publicly available due to preservation and vulnerability of E. orbicularis populations in Ukraine and Latvia.

Conflicts of Interest: The authors declare no conflict of interest.

\section{References}

1. Tytar, V.; Nekrasova, O.; Pupina, A.; Pupins, M.; Oskyrko, O. Long-term bioclimatic modelling the distribution of the fire-bellied toad, Bombina bombina, under the influence of global climate change. Vest. Zool. 2018, 52, 553-556. [CrossRef]

2. Nekrasova, O.D.; Gavris, G.G.; Kuybida, V.V. Changes in the Northern Border of the Home Range of the Dice Snake, Natrix tessellata (Reptilia, Colubridae), in the Dnipro Basin (Ukraine). Vest. Zool. 2013, 47, 475-479. [CrossRef]

3. Nekrasova, O.; Tytar, V.; Pupins, M. Bioclimatic limitations to the geographical distribution of Emys orbicularis (Linnaeus, 1758) (Testudines: Emydidae) in the North of the range. In Book of abstracts. XV Portuguese-Spanish Herpetology Congress and XIX Spanish Congress of Herpetology: "Biology and Conservation of Herps in the Anthropocene"; AHE and APH: Salamanca, Spain, 2018; pp. 121-122.

4. Kauhala, K.; Kowalczyk, R. Invasion of the raccoon dog Nyctereutes procyonoides in Europe: History of colonization, features behind its success, and threats to native fauna. Cur. Zool. 2011, 57, 584-598. [CrossRef] [PubMed]

5. Pupina, A.; Pupins, M.; Nekrasova, O.; Tytar, V.; Kozynenko, I.; Marushchak, O. Species distribution modelling: Bombina bombina (Linnaeus, 1761) and its important invasive threat Perccottus glenii (Dybowski, 1877) in Latvia under global climate change. Env. Res. Eng. Manag. 2018, 74, 79-86.

6. Balzani, P.; Vizzini, S.; Santini, G.; Masoni, A.; Ciofi, C.; Ricevuto, E.; Chelazzi, G. Stable isotope analysis of trophic niche in two co-occurring native and invasive terrapins, Emys orbicularis and Trachemys scripta elegans. Biol. Invasions 2016, 18, 3611-3621. [CrossRef]

7. Cadi, A.; Joly, P. Impact of the introduction of the red-eared slider (Trachemys scripta elegans) on survival rates of the European pond turtle (Emys orbicularis). Biodivers. Conserv. 2004, 13, 2511-2518. [CrossRef]

8. Cerasoli, F.; Iannella, M.; Biondi, M. Between the hammer and the anvil: How the combined effect of global warming and the non-native common slider could threaten the European pond turtle. Manag. Biol. Invasions 2019, 10, 428-448. [CrossRef]

9. Fritz, U. Zur innerartlichen variabilität von Emys orbicularis (Linnaeus, 1758). Intraspezifische Hierarchie und Zoogeographie (Reptilia: Testudines: Emydidae). Zool. Abh. Staatl. Mus. Tierkd. Dresd. 1996, 49, 31-71.

10. Fritz, U. Emys orbicularis (Linnaeus, 1758)—Europäische Sumpfschildkröte. In Handbuch der Reptilien und Amphibien Europas; Fritz, U., Schildkröten, I., Eds.; Aula: Wiebelsheim, Germany, 2001; pp. 343-515.

11. Sommer, R.S.; Persson, A.; Wiesecke, N.; Fritz, U. Holocene recolonization and extinction history of the pond turtle, Emys orbicularis (L., 1758), in Europe. Quat. Sci. Rev. 2007, 26, 3099-3107. [CrossRef]

12. Sommer, R.S.; Lindqvist, C.; Persson, A.; Bringsøe, H.; Rhodin, A.G.; Schneeweiss, N.; Široký, P.; Bachmann, L.; Fritz, U. Unexpected early extinction of the European pond turtle (Emys orbicularis) in Sweden and climatic impact on its Holocene range. Mol. Ecol. 2009, 18, 1252-1262. [CrossRef]

13. Nekrasova, O.; Yanish, Y.; Tytar, V.; Pupins, M. GIS-modeling of the Range Shifts of the Sub-fossil and Extant European Pond Turtle (Emys orbicularis) in Eastern Europe in Holocene. Diversity 2019, 11, 121. [CrossRef]

14. Nekrasova, O.; Tytar, V.; Pupins, M. Local functional responses of the European pond turtle, Emys orbicularis, to bioclimatic habitat features: A comparison of populations from Latvia and Ukraine. In Proceedings of the II Congresso Nazionale Testuggini e Tartarughe, Albenga, Italy, 11-13 April 2019; Ottonello, D., Oneto, F., Piccardo, P., Salvidio, S., Eds.; II Congresso Nazionale Testuggini e Tartarughe: Albenga, Italy, 2020; pp. 117-123.

15. Pupins, M.; Pupina, A. Project LIFE-HerpetoLatvia: First results on conservation of Emys orbicularis in Latvia. In Proceedings of the III International Conference-Workshop "Research and conservation of European herpetofauna and its environment: Bombina bombina, Emys orbicularis, and Coronella austriaca", Daugavpils, Latvia, 14-15 August 2014; Herpetological Facts Journal: Daugavpils, Latvia, 2015; (Suppl. 1), pp. 85-96. 
16. Pupins, M.; Nekrasova, O.; Marushchak, O.; Dubyna, A.; Neizhko, I. Morphological features of European pond turtles' Emys orbicularis (Linnaeus, 1758) hatchlings at the northern edge (Latvia) and central part (Ukraine) of its distribution range. In Proceedings of the II Congresso Nazionale Testuggini e Tartarughe, Albenga, Italy, 11-13 April 2019; Ottonello, D., Oneto, F., Piccardo, P., Salvidio, S., Eds.; II Congresso Nazionale Testuggini e Tartarughe: Albenga, Italy, 2020; pp. 144-150.

17. Drobenkov, S.M. Population ecology of European Pond Turtle in Belarus; Belaruskaya Nauka: Minsk, Belarus, 2012; 106p. (In Russian)

18. Bodie, J. Steam and riparian management for freshwater turtles. J. Environ. Manag. 2001, 62, 443-455. [CrossRef]

19. Ficetola, G.F.; De Bernardi, F. Is the European "pond" turtle Emys orbicularis strictly aquatic and carnivorous? Amph.-Rep. 2006, 27, 445-447. [CrossRef]

20. Kotenko, T.I. The European pond turtle (Emys orbicularis) in the Steppe Zone of the Ukraine. Stapfia 69 Zugleich Kat. OÖ. Landesmus. Neue Folge. 2000, 149, 87-106.

21. Marushchak, O.; Nekrasova, O.; Pupins, M.; Tytar, V.; Ceirans, A. The role and importance of the protected areas' (Emerald Network) development for amphibians and reptiles on the example of Ukraine in the context of various factors' influence. In Proceedings of the 12th International Scientific and Practical Conference "Environment. Technology. Resources", Rezekne, Latvia, 20-22 June 2019; Rezekne Academy of Technologies: Rezekne, Latvia, 2019; Volume 1, pp. 154-158. [CrossRef]

22. Kornilev, Y.; Popgeorgiev, G.; Naumov, B.; Stoyanov, A.; Tzankov, N. Updated distribution and ecological requirements of the native freshwater turtles in Bulgaria. Acta Zool. Bulg. 2017, 10, 65-76.

23. Zuffi, M.A.L. Biology of the conservation of the European pond turtle, Emys orbicularis, of Italy. Stapfia 2000, 69, $219-228$.

24. Kurtyak, F.; Kurtyak, M. Slider Turtle, Trachemys scripta elegans (Wied 1839) (Reptilia; Testudines), as invasion threat in Transcarpathia (Ukraine). Visn. Uzhh. Univ Series Biol. 2013, 34, 1-5. (In Ukrainian)

25. Ficetola, G.F.; Thuiller, W.; Padoa-Schioppa, E. From introduction to the establishment of alien species: Bioclimatic differences between presence and reproduction localities in the slider turtle. Divers. Distrib. 2009, 15, 108-116. [CrossRef]

26. Tzankov, N.; Popgeorgiev, G.; Kornilev, Y.; Natchev, N.; Stoyanov, A.; Naumov, B.; Ivanchev, I. First survey on the invasive Pond slider (Trachemys scripta) in Bulgaria: Historic development and current situation. Hyla 2015, 2015, 18-27.

27. Koren, T.; Štih, A.; Burić, I.; Koller, K.; Lauš, B.; Zadravec, M. The current distribution of pond slider Trachemys scripta (Reptilia: Emydidae) in Croatia. Nat. Slov. 2018, 20, 33-44.

28. Zagorodniuk, I. Adventive theriofauna of Ukraine and the importance of invasions in historical changes of fauna and groups. Proc. Theriol. Sch. 2006, 8, 18-47. (In Ukrainian)

29. Nekrasova, O.D.; Marushchak, O.Y. Findings of amphibians and reptiles from protection lists of Resolution 6 of Bern Convention in Ukraine. In Records of protected animal, plant and fungi species in Ukraine: Series «Conservation Biology in Ukraine»; Tvory: Vinnytsia, Ukraine, 2020; Volume 19, pp. 339-341. (In Ukrainian)

30. Pupins, M.; Pupina, A. Distribution of European pond turtle Emys orbicularis (Linnaeus, 1758) on the northern edge of its area in Latvia. Rev. Esp. Herp. 2008, 22, 149-157.

31. Fritz, U. Introduction to zoogeography and subspecific differentiation in Emys orbicularis (Linnaeus, 1758). In Proceedings of the EMYS Symposium Dresden, 1998; Volume 96, pp. 1-27. Available online: https://www.researchgate.net/profile/UweFritz/publication/304353853_Introduction_to_zoogeography_and_subspecific_differentiation_in_Emys_orbicularis_Linnaeus_ 1758/links/576d073f08ae0639beeb4299/Introduction-to-zoogeography-and-subspecific-differentiation-in-Emys-orbicularisLinnaeus-1758.pdf (accessed on 27 April 2021).

32. Fritz, U.; Laufer, H. Europaische Sumpfschildkrote, Emys orbicularis (Linnaeus, 1758). In Die Amphibien und Reptilien BadenWurttembergs; Laufer, H., Fritz, C., Sowig, P., Eds.; Ulmer: Stuttgart, Germany, 2007; pp. 511-524.

33. Emys orbicularis (Linnaeus, 1758) in GBIF.org (03 April 2021) GBIF Occurrence. [CrossRef]

34. Nyctereutes procyonoides (Gray, 1834) in GBIF.org (03 April 2021) GBIF Occurrence. [CrossRef]

35. Trachemys scripta (Thunberg In Schoepff, 1792) in GBIF.org (03 April 2021) GBIF Occurrence. [CrossRef]

36. Osorio-Olvera, L.; Lira-Noriega, A.; Soberón, J.; Peterson, A.T.; Falconi, M.; Contreras-Díaz, R.G. ntbox: An r package with graphical user interface for modelling and evaluating multidimensional ecological niches. Methods Ecol. Evol. 2020, 11, 1199-1206. [CrossRef]

37. Kriticos, D.J.; Jarošik, V.; Ota, N. Extending the suite of bioclim variables: A proposed registry system and case study using principal components analysis. Methods Ecol. Evol. 2014. Online Early. [CrossRef]

38. Guisan, A.; Zimmerman, N.E. Predictive habitats distribution models, in ecology. Ecol. Model. 2000, 135, 147-186. [CrossRef]

39. Leroy, B.; Meynard, C.N.; Bellard, C.; Courchamp, F. Virtualspecies, an R package to generate virtual species distributions. Ecography 2016, 39, 599-607. [CrossRef]

40. Venter, O.; Sanderson, E.; Magrach, W.; Ainhoa, A.; Beher, J.R.; Jones, J.; Possingham, K.R.; Laurance, H.P.; Wood, W.F.; Fekete, P.; et al. Global terrestrial Human Footprint maps for 1993 and 2009. Sci. Data. 2016, 23, 160067-160077. [CrossRef]

41. Iannella, M.; Cerasoli, F.; D'Alessandro, P.; Console, G.; Biondi, M. Coupling GIS spatial analysis and Ensemble Niche Modelling to investigate climate change-related threats to the Sicilian pond turtle Emys trinacris, an endangered species from the Mediterranean. PeerJ 2018, 6, e4969. [CrossRef]

42. Tytar, V.; Nekrasova, O.; Pupins, M. Positive Relationships Between Human Impact and Biodiversity: The Case of the Fire-Bellied Toad (Bombina bombina) in Europe. In Proceedings of the 12th International Scientific and Practical Conference "Environment. Technology. Resources", Rezekne, Latvia, 20-22 June 2019; Rezekne Academy of Technologies: Rezekne, Latvia, 2019; Volume 1, pp. 311-314. [CrossRef] 
43. Phillips, S.J. A brief tutorial on Maxent. ATET Res. 2005, 190, 231-259.

44. Araújo, M.B.; Pearson, R.G.; Thuiller, W.; Erhard, M. Validation of species-climate impact models under climate change. Global Chang. Biol. 2005, 11, 1504-1513. [CrossRef]

45. Nekrasova, O.D.; Tytar, V.M.; Kuybida, V.V. GIS modeling of climate change vulnerability of amphibians and reptiles in Ukraine. In NAS of Ukraine, Schmalhausen Institute of Zoology NAS; National Fund of Fundamental Research: Kyiv, Ukraine, 2019; 204p, ISBN 978-966-02-8956-7. (In Ukrainian)

46. Pupins, M.; Tytar, V.; Nekrasova, O.; Ceirans, A. Modelling co-occurrence patterns of the invasive Pond Slider (Trachemys scripta) and the native European Pond Turtle (Emys orbicularis) in Europe. In Proceedings of the Scientific Conference and 9th ESENIAS Workshop "Species, Ecosystems and Areas of Conservation Concern under Threat from the Invasive alien Species", Ohrid, Republic of North Macedonia, 3-6 September 2019; DIAS Scientific Conference: Ohrid, Republic of North Macedonia, 2019.

47. Bakharev, V.A. The history of the area Emys orbicularis (Testudines, Emydidae) and the current state of its borders within Belarus. Praci Ukr. Gerpetol. Tov. 2014, 5, 12-19. (In Russian) 